\title{
Dietary interrelationships among arginine, methionine, and lysine in young broiler chicks
}

\author{
M. Chamruspollert, G. M. Pesti* and R. I. Bakalli \\ Department of Poultry Science, The University of Georgia, Athens, Georgia 30602-2772, USA
}

(Received 5 September 2001 - Revised 30 July 2002 - Accepted 11 August 2002)

\begin{abstract}
Since excess dietary lysine (Lys) can increase the chick's arginine (Arg) requirement and excess Arg can increase the chick's methionine (Met) requirement, experiments were conducted to test the hypothesis that responses to dietary Lys and Met are also interrelated. Day-old Ross $\times$ Ross chicks were fed a maize-soyabean meal-based diet supplemented with four levels of L-Arg $(0,5,10$ or $20 \mathrm{~g} / \mathrm{kg})$, factorially arranged with four levels of supplemental DL-Met $(0,1$, 2 or $3 \mathrm{~g} / \mathrm{kg}$ ). Three replicate pens of ten chicks each were randomly assigned to each treatment and fed for $14 \mathrm{~d}$. An increase in Arg in the diet caused growth and feed-intake depression $(P=0 \cdot 0001)$, but increasing Met in the diet enhanced growth and feed intake $(P=0 \cdot 0001)$. Arg toxicity was dependent on the Met level of the diet (Arg $\times$ Met interaction; $P=0.0153)$. Experiment 2 was conducted to study interrelationships among Arg, Met, and Lys. Eight treatments were factorially combined: two levels of supplemental L-Arg $(0$ or $10 \mathrm{~g} / \mathrm{kg}$ ), two levels of supplemental DL-Met (0 or $2 \mathrm{~g} / \mathrm{kg}$ ), and two levels of supplemental L-Lys $(0$ or $6 \mathrm{~g} / \mathrm{kg})$. Six replicate pens of eight chicks per treatment were used. A three-way interaction among Arg, Met, and Lys was observed for body-weight gain and feed intake $(P<0.023)$. As expected, kidney arginase activity increased as dietary Lys increased $(P=0.0004)$. No interactions were found for kidney arginase activity. Muscle creatine increased when chicks were fed the higher $\operatorname{Arg}(25.2 \mathrm{~g} / \mathrm{kg})$ diet $(P=0.0047)$. A three-way interaction among Arg, Met, and Lys was found for muscle creatine $(P=0.0075)$. Excess dietary Lys depressed muscle creatinine concentration, but only in the presence of the lower concentrations of Arg and Met. To conclude, an interrelationship among Arg, Met, and Lys was demonstrated, and it was probably related to creatine biosynthesis.
\end{abstract}

Arginine-methionine interaction: Arginine-lysine interaction: Arginase: Creatine

Anderson \& Dobson (1959) were among the first to observe a relationship between the dietary lysine (Lys) and arginine (Arg) requirements of broilers. Several other subsequent reports contained similar observations (Lewis et al. 1963; Jones, 1964; Smith \& Lewis, 1966; D’Mello \& Lewis, 1970). Dean \& Scott (1968) reported that the addition of excess Lys to a basal diet retarded the growth of chicks, but that further supplementation of the diet with Arg would alleviate the poor growth response. They concluded that the Arg requirement was higher when the diet contained more Lys (Arg $\times$ Lys interaction). Later it was discovered that excess dietary Lys did increase the dietary Arg requirement of chicks, since the activity of the Arg catabolizing enzyme, arginase, was stimulated by increasing the dietary concentration of Lys (Nesheim, 1968).

A relationship between Arg and methionine (Met) in broiler chicks was also observed. Keshavarz \& Fuller $(1971 b)$ reported that the addition of $\operatorname{Arg}(20 \mathrm{~g} / \mathrm{kg})$ to a maize-soyabean-meal diet decreased the growth rate of chicks and the growth depression could be alleviated by supplementing the diet with Met $(2 \mathrm{~g} / \mathrm{kg})$. They suggested that at least one of the mechanisms involved in the interaction between Arg and Met was the formation of muscle creatine. Fisher et al. (1956) reported that during the first 4 weeks of life, creatine biosynthesis was an important factor in the Arg metabolism in chicks. This initial observation by Fisher et al. (1956), however, appears not to have been investigated further.

Creatine, as a precursor of creatine phosphate, has two important roles in normal muscle function: it carries high-energy phosphate from mitochondria to myosin filaments; it acts as a reservoir of high-energy phosphate that can regenerate ATP from ADP (Marks et al. 1996). 
When creatine spontaneously cyclizes to form creatinine, it can no longer be metabolized and must be excreted from the body. Anything that influences creatine synthesis or creatinine excretion has the potential to make less Arg available for protein synthesis and growth.

Due to the relationships between Arg and Lys as well as Arg and Met, we hypothesized that in young broiler chicks there could be an interrelationship among Arg, Lys, and Met involving arginase and/or creatine formation. Any dietary interactions between Lys and Met have not been documented. Therefore, the current studies were conducted to confirm the dietary Arg and Met interrelationship and test the hypothesis that there was a relationship among dietary Arg, Met, and Lys levels that could affect chick growth.

\section{Materials and methods}

\section{Experiment 1}

Day-old female broiler chicks (Ross $\times$ Ross 208; Ross Breeders Inc., Huntsville, AL 35805, USA) were obtained from a commercial hatchery (Seaboard Farms of Athens, Athens, GA 30601, USA). Birds were wing-banded, weighed, and randomly assigned to individual pens in raised wire-floored batteries (Petersime Incubator Co., Gettysburg, OH 54238, USA). There were three replicate pens of ten chicks each per dietary treatment. A maizesoyabean-meal diet formulated to meet the requirements (National Research Council, 1994) for all nutrients except for the S-containing amino acids was used as a basal diet (Table 1). There were sixteen treatments with

Table 1. Composition and nutrient content of the basal diet

\begin{tabular}{|c|c|}
\hline & Composition $(\mathrm{g} / \mathrm{kg})$ \\
\hline \multicolumn{2}{|l|}{ Ingredients } \\
\hline Maize & 534.5 \\
\hline Soyabean meal & $377 \cdot 2$ \\
\hline Poultry fat & $59 \cdot 6$ \\
\hline Defluorinated phosphate & $17 \cdot 0$ \\
\hline Limestone & $6 \cdot 4$ \\
\hline Common salt & $4 \cdot 0$ \\
\hline Mineral premix ${ }^{*}$ & 0.8 \\
\hline Vitamin premix $†$ & 0.5 \\
\hline \multicolumn{2}{|l|}{ Calculated composition $\ddagger$} \\
\hline Metabolizable energy (MJ/kg) & $13 \cdot 39$ \\
\hline $\mathrm{Ca}(\mathrm{g} / \mathrm{kg})$ & $9 \cdot 0$ \\
\hline Available P (g/kg) & 4.5 \\
\hline Crude protein $(\mathrm{g} / \mathrm{kg})$ & $230 \cdot 0$ \\
\hline Choline (mg/kg) & 1400 \\
\hline Arginine $(\mathrm{g} / \mathrm{kg})$ & $15 \cdot 2$ \\
\hline Methionine $(\mathrm{g} / \mathrm{kg})$ & 3.5 \\
\hline Cystine $(\mathrm{g} / \mathrm{kg})$ & $3 \cdot 7$ \\
\hline Lysine $(\mathrm{g} / \mathrm{kg})$ & $12 \cdot 6$ \\
\hline Glycine + serine (g/kg) & $24 \cdot 6$ \\
\hline
\end{tabular}

* Trace mineral premix provided the following (mg/kg diet): $\mathrm{Mn}, 60 ; \mathrm{Zn}, 50$; $\mathrm{Fe}, 30 ; \mathrm{Cu}, 5 ; \mathrm{I}, 1.5$.

†Vitamin premix provided the following (/kg diet): vitamin A, $1892 \mu \mathrm{g}$ from trans-retinyl acetate; cholecalciferol, $27.5 \mu \mathrm{g}$; vitamin $\mathrm{E}, 11 \mathrm{mg}$ from all-ractocopherol acetate; riboflavin, $4.5 \mathrm{mg}$; calcium pantothenate, $12 \mathrm{mg}$; nicotinic acid, $44 \mathrm{mg}$; choline cloride, $220 \mathrm{mg}$; vitamin $\mathrm{B}_{12}, 6.6 \mu \mathrm{g}$; vitamin $\mathrm{B}_{6}$, $2.2 \mathrm{mg}$; menadione, $1.1 \mathrm{mg}$; (as menadione sodium bisulfate complex); folic acid, $0.55 \mathrm{mg}$; d-biotin, $0.11 \mathrm{mg}$; thiamine, $1.1 \mathrm{mg}$ (as thiamine mononitrate); ethoxyquin, $125 \mathrm{mg}$.

$\ddagger$ National Research Council (1994). four levels of supplemental L-Arg (L-Arginine-HCl; Seltzer Chemical, Inc., Carlsbad, CA 92008-7305, USA) (0, 5,10 or $20 \mathrm{~g} / \mathrm{kg}$ ) and four levels of supplemental DL-Met (Degussa Corporation, Kennesaw, GA 30144, USA) (0, 1,2 or $3 \mathrm{~g} / \mathrm{kg}$ ). Due to the high percentage of L-Arg used in the present experiment, cellulose was added to equalize other nutrient concentrations. Feed and water were provided for ad libitum consumption. The experiment was conducted for $14 \mathrm{~d}$. Body-weight gain, feed intake, and feed conversion ratio (FCR) were measured from 1 to $14 \mathrm{~d}$ of age.

\section{Experiment 2}

\section{Animals}

Ross $\times$ Ross 208 broiler chicks were locally hatched. Six replicate pens of eight unsexed chicks per dietary treatment were used. The basal diet (Table 1) was supplemented with two levels of L-Arg ( 0 or $10 \mathrm{~g} / \mathrm{kg})$, of DL-Met $(0$ or $2 \mathrm{~g} / \mathrm{kg})$, and of L-Lys (BASF INC., Mount Olive, NJ 07828, USA) $(0$ or $6 \mathrm{~g} / \mathrm{kg})$ in a factorial arrangement. At the end of the $14 \mathrm{~d}$ experimental period, three chicks from each pen were randomly chosen and killed by $\mathrm{CO}_{2}$ asphyxiation. Whole kidneys and breast muscles from each chick were taken and pooled by pen for arginase and creatine analysis, respectively.

\section{Tissue preparation}

For the kidneys, fresh homogenates $(100 \mathrm{~g} / \mathrm{kg})$ were prepared in $0.02-\mathrm{M}$ potassium phosphate buffer, $\mathrm{pH} 7 \cdot 5$, by homogenizing the tissue for $20 \mathrm{~s}$ with a motor-driven Ultra-Turrax T25 homogenizer (J\&K IKA-Works, Inc., Cincinnati, OH 45240, USA). The mixture was chilled in ice during the collection process and then stored at $-80^{\circ} \mathrm{C}$ until the analysis.

Breast muscles were pooled and chopped into pieces no larger than $2 \mathrm{~mm}$. Muscle $(1 \mathrm{~g})$ was placed into a $25 \times$ $150 \mathrm{~mm}$ test tube with $1-\mathrm{M}$ sulfuric acid $(20 \mathrm{ml})$. After all samples were collected and mixed with sulfuric acid, they were autoclaved for $45 \mathrm{~min}$ at $1.1 \mathrm{~kg} / \mathrm{cm}^{2}$ pressure. Samples were stored at $4^{\circ} \mathrm{C}$ until analysis.

\section{Arginase and protein assays}

Arginase activity was measured by the rate of urea formation. The assay was identical to the assay described by Tamir \& Ratner (1963), except the kidney homogenate was diluted to 1:25 with potassium phosphate buffer and diluted homogenate $(0.8 \mathrm{ml})$ was used for the assay. The urea formed was estimated by the colorimetric procedure of Van Slyke \& Archibald (1946). The sulfuric-phosphoric acids mixture was used as modified by O'Dell et al. (1965). One unit of arginase activity was defined as $1 \mu \mathrm{mole}$ urea formed/h per $\mathrm{mg}$ kidney protein at $38^{\circ} \mathrm{C}$. Protein was determined by the method of Lowry et al. (1951) using bovine serum albumin as a standard. 


\section{Muscle creatine analysis}

The method of Rose et al. (1927) was modified for the determination of muscle creatine. Samples were transferred to $100 \mathrm{ml}$ volumetric flasks. Sample tubes were rinsed twice with deionized water to remove all contents. $\mathrm{NaOH}(2-\mathrm{M}, 18 \mathrm{ml})$ was added to each flask, followed by sodium tungstate $(100 \mathrm{~g} / \mathrm{kg}, 5 \mathrm{ml})$. The flasks were filled to $100 \mathrm{ml}$ with deionized water. Samples were shaken well and then allowed to stand for $5 \mathrm{~min}$ before being filtered (Filter Paper no. 1; Whatman Inc., Clifton, NJ 07014, USA). The clear filtrate $(10 \mathrm{ml})$ was placed into another $100 \mathrm{ml}$ volumetric flask, and $5 \mathrm{ml}$ of alkaline picrate (fresh mixture of $50 \mathrm{ml}$ saturated picric acid (saturated solution; Sigma Diagnostics, St. Louis, MO 63178, USA) and $\mathrm{NaOH}(10 \mathrm{ml}, 100 \mathrm{~g} / \mathrm{kg}))$ was added to convert creatine to creatinine. Samples were then mixed well and allowed to stand for $10 \mathrm{~min}$. The samples were diluted to $100 \mathrm{ml}$ with deionized water. A creatinine (anhydrous; Sigma Chemical Co., St. Louis, MO 63178, USA) standard stock solution $(500 \mu \mathrm{g} / \mathrm{ml})$ was prepared and a standard curve $(0-1 \mathrm{mg})$ was made. Absorbance of the samples and standards was read in a spectrophotometer at $450 \mathrm{~nm}$.

\section{Statistical analysis}

The experimental unit was the pen mean. FCR, arginase, and muscle creatine data were analysed using the general linear model procedure of $\mathrm{SAS}^{\circledR}{ }^{\circledR}$ (SAS Institute, 1985) for ANOVA. Body gain and feed intake data were analysed by analysis of covariance (Montgomery, 1997). Differences among means were determined by Duncan's new multiple range test (Steel \& Torrie, 1980).

\section{Results and discussion}

Experiment 1 confirmed the results of Keshavarz \& Fuller $(1971 a, b)$ and established that our model system, with a much faster growing broiler, would give similar results. We demonstrated the Met $\times$ Arg interaction for broiler chick growth (Table 2). Considering the main effect means, an increase in Arg in the diet caused growth and feed-intake depression $(P=0.0001)$; on the other hand, increasing Met in the diet enhanced growth and feed intake $(P=0 \cdot 0001)$. FCR (feed:gain) was significantly improved by additional Met $(P=0 \cdot 0001)$ in the diet up to $6.5 \mathrm{~g} / \mathrm{kg}$ in the present study. However, graded levels of Arg had no consistent effect on FCR $(P=0 \cdot 0547)$.

Table 2. The effect of levels of arginine and methionine on average body-weight gain, feed intake and feed conversion ratio (Feed:gain) of chicks ( $n 10$ per replication per treatment) fed with a maize-soyabean meal basal diet for $14 \mathrm{~d}$ (Experiment 1$)^{*}$

(Mean values with their standard errors)

\begin{tabular}{|c|c|c|c|c|c|c|c|}
\hline \multirow[b]{2}{*}{ Arginine (g/kg diet) } & \multirow[b]{2}{*}{ Methionine ( $\mathrm{g} / \mathrm{kg}$ diet) } & \multicolumn{2}{|c|}{$\begin{array}{l}\text { Average body- } \\
\text { weight gain } \\
(g / 14 d)\end{array}$} & \multicolumn{2}{|c|}{$\begin{array}{c}\text { Feed intake } \\
(\mathrm{g} / \text { chick per } 14 \mathrm{~d})\end{array}$} & \multicolumn{2}{|c|}{ Feed:gain (g/g) } \\
\hline & & Mean & SE & Mean & se & Mean & SE \\
\hline $15 \cdot 2$ & 3.5 & $319^{c}$ & 6 & $442^{\mathrm{bc}}$ & 5 & $1 \cdot 39^{a b}$ & 0.02 \\
\hline $20 \cdot 2$ & 3.5 & $251^{d}$ & 20 & $369^{d}$ & 10 & $1.44^{\mathrm{a}}$ & 0.06 \\
\hline $25 \cdot 2$ & 3.5 & $217^{\text {de }}$ & 18 & $310^{\mathrm{e}}$ & 17 & $1.44^{\mathrm{a}}$ & 0.05 \\
\hline $35 \cdot 2$ & 3.5 & $189^{\mathrm{e}}$ & 12 & $251^{f}$ & 17 & $1 \cdot 32^{\text {cde }}$ & 0.04 \\
\hline $15 \cdot 2$ & 4.5 & $377^{\mathrm{ab}}$ & 4 & $494^{\mathrm{ab}}$ & 5 & $1 \cdot 31^{\text {bcde }}$ & 0.005 \\
\hline $20 \cdot 2$ & 4.5 & $356^{\mathrm{abc}}$ & 5 & $464^{\mathrm{abc}}$ & 12 & $1 \cdot 30^{\mathrm{bcde}}$ & 0.02 \\
\hline $25 \cdot 2$ & 4.5 & $336^{\mathrm{bc}}$ & 11 & $459^{a b c}$ & 11 & $1 \cdot 36^{\mathrm{abc}}$ & 0.02 \\
\hline $35 \cdot 2$ & 4.5 & $259^{d}$ & 26 & $337^{\text {de }}$ & 26 & $1 \cdot 31^{\text {bcde }}$ & 0.04 \\
\hline $15 \cdot 2$ & $5 \cdot 5$ & $372^{\mathrm{abc}}$ & 13 & $473^{a b c}$ & 9 & $1 \cdot 28^{\text {cde }}$ & 0.02 \\
\hline $20 \cdot 2$ & $5 \cdot 5$ & $344^{\mathrm{bc}}$ & 6 & $430^{c}$ & 16 & $1 \cdot 25^{\mathrm{de}}$ & 0.02 \\
\hline $25 \cdot 2$ & $5 \cdot 5$ & $363^{\mathrm{abc}}$ & 30 & $461^{a b c}$ & 30 & $1 \cdot 27^{\text {cde }}$ & 0.03 \\
\hline $35 \cdot 2$ & $5 \cdot 5$ & $364^{\mathrm{abc}}$ & 14 & $454^{\mathrm{abc}}$ & 17 & $1 \cdot 25^{\mathrm{de}}$ & 0.01 \\
\hline $15 \cdot 2$ & $6 \cdot 5$ & $409^{a}$ & 26 & $507^{a}$ & 16 & $1 \cdot 25^{\mathrm{de}}$ & 0.04 \\
\hline $20 \cdot 2$ & 6.5 & $385^{\mathrm{ab}}$ & 20 & $466^{a b c}$ & 27 & $1 \cdot 21^{\mathrm{e}}$ & 0.02 \\
\hline $25 \cdot 2$ & $6 \cdot 5$ & $383^{a b}$ & 10 & $487^{\mathrm{abc}}$ & 10 & $1 \cdot 27^{\text {cde }}$ & 0.04 \\
\hline $35 \cdot 2$ & $6 \cdot 5$ & $360^{\mathrm{abc}}$ & 11 & $435^{\mathrm{bc}}$ & 24 & $1 \cdot 20^{\mathrm{e}}$ & 0.03 \\
\hline \multicolumn{8}{|l|}{ Main effect means } \\
\hline Arginine (g/kg diet): 15.2 & & 369 & 12 & 479 & 8 & $1 \cdot 31$ & 0.02 \\
\hline $20 \cdot 2$ & & 334 & 16 & 432 & 14 & $1 \cdot 30$ & 0.03 \\
\hline $25 \cdot 2$ & & 325 & 21 & 429 & 22 & 1.34 & 0.03 \\
\hline $35 \cdot 2$ & & 293 & 23 & 369 & 26 & $1 \cdot 27$ & 0.02 \\
\hline Methionine ( $\mathrm{g} / \mathrm{kg}$ diet): 3.5 & & 244 & 16 & 343 & 22 & 1.40 & 0.02 \\
\hline 4.5 & & 332 & 15 & 439 & 19 & 1.32 & 0.01 \\
\hline 5.5 & & 361 & 8 & 455 & 10 & $1 \cdot 26$ & 0.01 \\
\hline $6 \cdot 5$ & & 384 & 9 & 474 & 12 & $1 \cdot 23$ & 0.02 \\
\hline \multicolumn{8}{|l|}{ ANOVA } \\
\hline Arginine, $\mathrm{df}=3, P=$ & & \multicolumn{2}{|c|}{0.0001} & \multicolumn{2}{|c|}{0.0001} & \multicolumn{2}{|c|}{0.0547} \\
\hline Methionine, $\mathrm{df}=3, P=$ & & \multicolumn{2}{|c|}{0.0001} & \multicolumn{2}{|c|}{0.0001} & \multicolumn{2}{|c|}{0.0001} \\
\hline Interaction, $\mathrm{df}=10, P=$ & & \multicolumn{2}{|c|}{0.0153} & \multicolumn{2}{|c|}{0.0004} & \multicolumn{2}{|c|}{0.7207} \\
\hline
\end{tabular}

$\mathrm{a}, \mathrm{b}, \mathrm{c}, \mathrm{d}, \mathrm{e}, \mathrm{f}$ Mean values within a column with unlike superscript letters were significantly different $(P<0.05)$.

${ }^{*}$ For details of diets and procedures, see Table 1 and p. 656. 


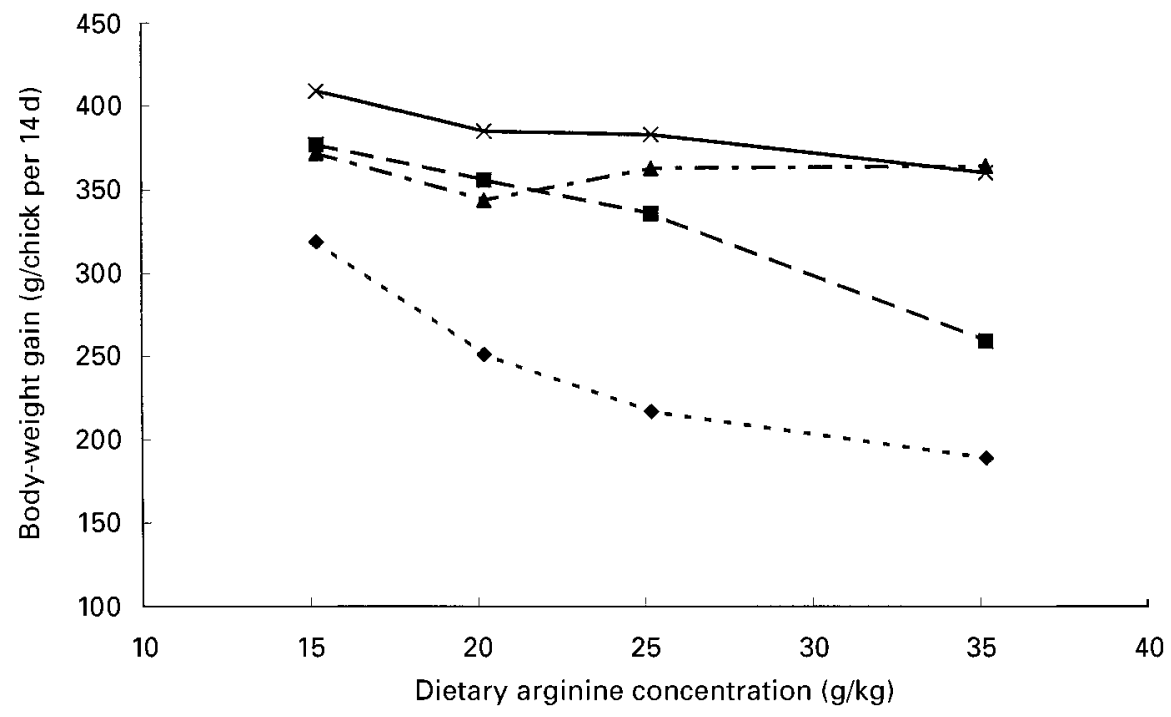

Fig. 1. The relationship between arginine and graded levels of methionine $((-\bullet-), 3.5 \mathrm{~g}$ methionine/kg diet; (- - $)$, $4.5 \mathrm{~g}$ methionine/kg diet; (-- $\mathbf{-}--), 5.5 \mathrm{~g}$ methionine $/ \mathrm{kg}$ diet; $(-\times-), 6.5 \mathrm{~g}$ methionine/kg diet) based on body-weight gain data (Experiment 1).

The growth decline caused by higher Arg was most severe when the diet contained limiting levels of Met and the depression could be alleviated by adding small amounts of Met (Fig. 1). However, levels of Met to relieve the adverse effect was dependent upon Arg levels in the diet.
The growth depression caused by graded levels of Arg up to $25 \cdot 2 \mathrm{~g} / \mathrm{kg}$ in the Met-deficient $(3.5 \mathrm{~g} / \mathrm{kg})$ diet was overcome with $1 \mathrm{~g}$ additional DL-Met/kg (Table 2 and Fig. 1). When the Met-deficient diet containing the highest level of $\operatorname{Arg}(35 \cdot 2 \mathrm{~g} / \mathrm{kg})$ was fed, the growth depression was

Table 3. The effect of levels of arginine, methionine, and lysine on average body-weight gain, feed intake and feed conversion ratio (Feed: gain) of chicks ( $n 8$ per replication per treatment) fed with a maize-soyabean meal basal diet for $14 \mathrm{~d}$ (Experiment 2$)^{*}$

(Mean values with their standard errors)

\begin{tabular}{|c|c|c|c|c|c|c|c|c|}
\hline \multirow[b]{2}{*}{ Arginine ( $\mathrm{g} / \mathrm{kg}$ diet) } & \multirow{2}{*}{$\begin{array}{l}\text { Methionine } \\
\text { (g/kg diet) }\end{array}$} & \multirow{2}{*}{$\begin{array}{l}\text { Lysine } \\
\text { (g/kg diet) }\end{array}$} & \multicolumn{2}{|c|}{$\begin{array}{c}\text { Average } \\
\text { body-weight } \\
\text { gain (g/14d) }\end{array}$} & \multicolumn{2}{|c|}{$\begin{array}{c}\text { Feed intake } \\
\text { (g/chick per } \\
14 \mathrm{~d})\end{array}$} & \multicolumn{2}{|c|}{ Feed:gain $(\mathrm{g} / \mathrm{g})$} \\
\hline & & & Mean & SE & Mean & $\mathrm{SE}$ & Mean & $\mathrm{SE}$ \\
\hline $15 \cdot 2$ & 3.5 & $12 \cdot 6$ & $260^{\circ}$ & 8 & $347^{\mathrm{C}}$ & 14 & $1.33^{b c}$ & 0.02 \\
\hline $15 \cdot 2$ & 5.5 & $12 \cdot 6$ & $313^{\mathrm{ab}}$ & 10 & $387^{\mathrm{ab}}$ & 18 & $1 \cdot 24^{\mathrm{d}}$ & 0.03 \\
\hline $15 \cdot 2$ & 3.5 & $18 \cdot 6$ & $265^{\mathrm{c}}$ & 8 & $357^{\mathrm{bc}}$ & 11 & $1.35^{\mathrm{b}}$ & 0.03 \\
\hline $15 \cdot 2$ & 5.5 & $18 \cdot 6$ & $303^{b}$ & 10 & $397^{\mathrm{a}}$ & 14 & $1 \cdot 31^{\mathrm{c}}$ & 0.03 \\
\hline $25 \cdot 2$ & 3.5 & $12 \cdot 6$ & $213^{d}$ & 4 & $287^{d}$ & 9 & 1.35 & 0.05 \\
\hline $25 \cdot 2$ & 5.5 & $12 \cdot 6$ & $328^{\mathrm{a}}$ & 7 & $416^{\mathrm{a}}$ & 10 & $1 \cdot 27^{\mathrm{d}}$ & 0.01 \\
\hline $25 \cdot 2$ & 3.5 & $18 \cdot 6$ & $213^{d}$ & 3 & $286^{d}$ & 3 & $1.34^{\mathrm{a}}$ & 0.02 \\
\hline $25 \cdot 2$ & 5.5 & $18 \cdot 6$ & $326^{\mathrm{ab}}$ & 9 & $405^{a}$ & 11 & $1 \cdot 24^{\mathrm{d}}$ & 0.01 \\
\hline \multicolumn{9}{|l|}{ Main effect means } \\
\hline Arginine ( $\mathrm{g} / \mathrm{kg}$ diet): $15 \cdot 2$ & & & 285 & 7 & 373 & 9 & $1 \cdot 31$ & 0.02 \\
\hline $25 \cdot 2$ & & & 270 & 12 & 349 & 13 & $1 \cdot 29$ & 0.03 \\
\hline Methionine (g/kg diet): 3.5 & & & 238 & 5 & 319 & 8 & 1.34 & 0.02 \\
\hline 5.5 & & & 318 & 5 & 401 & 6 & $1 \cdot 26$ & 0.02 \\
\hline Lysine (g/kg diet): $12 \cdot 6$ & & & 279 & 11 & 359 & 13 & 1.29 & 0.03 \\
\hline $18 \cdot 6$ & & & 277 & 10 & 361 & 11 & $1 \cdot 30$ & 0.02 \\
\hline \multicolumn{9}{|l|}{ ANOVA and analysis of covariance } \\
\hline Arginine, $\mathrm{df}=1, P=$ & & & \multicolumn{2}{|c|}{0.0100} & \multicolumn{2}{|c|}{0.0081} & \multicolumn{2}{|c|}{0.0863} \\
\hline Methionine, $\mathrm{df}=1, P=$ & & & \multicolumn{2}{|c|}{0.0001} & \multirow{2}{*}{\multicolumn{2}{|c|}{$\begin{array}{l}0.0001 \\
0.7388\end{array}$}} & \multicolumn{2}{|c|}{0.0001} \\
\hline Lysine, $\mathrm{df}=1, P=$ & & & \multirow{2}{*}{\multicolumn{2}{|c|}{$\begin{array}{l}0.8158 \\
0.0010\end{array}$}} & & & \multirow{2}{*}{\multicolumn{2}{|c|}{0.0008}} \\
\hline Arginine $\times$ methionine, $\mathrm{df}=1, P=$ & & & & & \multicolumn{2}{|c|}{0.0001} & & \\
\hline Arginine $\times$ lysine $, \mathrm{df}=1, P=$ & & & & \multicolumn{2}{|c|}{0.0018} & \multicolumn{2}{|c|}{0.0305} \\
\hline Methionine $\times$ lysine $, \mathrm{df}=1, P=$ & & & \multicolumn{2}{|c|}{$0 \cdot 1026$} & \multicolumn{2}{|c|}{0.2216} & \multicolumn{2}{|c|}{0.2964} \\
\hline Arginine $\times$ methionine $\times$ lysine, $\mathrm{df}=1, P=$ & & & \multirow{2}{*}{\multicolumn{2}{|c|}{0.0116}} & \multirow{2}{*}{\multicolumn{2}{|c|}{$\begin{array}{l}0.0230 \\
0.0001\end{array}$}} & \multirow{2}{*}{\multicolumn{2}{|c|}{0.0831}} \\
\hline Gain, $\mathrm{df}=1, P=$ & & & & & & & & \\
\hline Consumption, $\mathrm{df}=1, P=$ & & & \multicolumn{2}{|c|}{0.0001} & & & & \\
\hline
\end{tabular}

a,b,c,d Mean values within a column with unlike superscript letters were significantly different $(P<0.05)$.

${ }^{*}$ For details of diets and procedures, see Table 1 and p. 656 
relieved only by higher levels of Met (5.5 and 6.5 g Met/ $\mathrm{kg}$ ). In the present experiment we observed significant interactions between Arg and Met on average bodyweight gain $(P=0.0153)$ and feed consumption $(P=0.0004)$. However, we did not find an interaction for FCR $(P=0 \cdot 7207)$

These results are in agreement with studies done by Fuller et al. (1967) and Keshavarz \& Fuller (1971a,b) who demonstrated that excess dietary Arg caused a growth depression in chicks, which could be alleviated by supplemental Met. They suggested that growth depression with graded levels of added Arg could result from withdrawing more methyl groups from Met for creatine formation and consequently augmenting a Met deficiency (Keshavarz \& Fuller, 1971a,b).

Overall chick performance in Experiment 2 was not as good as in Experiment 1 (Table 3). Even though we used the same genetic stock (Ross $\times$ Ross 208) in both experiments, the hatchery and experimental environment may have caused the variation in growth. Body-weight gain was highest in chicks fed the diet containing $5.5 \mathrm{~g} \mathrm{Met} / \mathrm{kg}$ and lowest in those fed the diet containing the basal Met level $(3.5 \mathrm{~g} \mathrm{Met} / \mathrm{kg})(P=0.0001)$, demonstrating that the basal diet was deficient in Met (Table 3). Feeding the $25.2 \mathrm{~g} \mathrm{Arg} / \mathrm{kg}$-containing diet to chicks decreased their body-weight gains $(P=0 \cdot 01)$. Three-way interactions among Arg, Met, and Lys were observed $(P<0.05)$, for weight gain and feed intake. At the lower Arg level, the growth response to Met was dependent on Lys level. At the high Arg level, there was no difference in the growth response to Met due to Lys level.

As expected, an increase in kidney arginase activity from 45 to $77 \mu \mathrm{mol}$ urea/h per mg protein was caused by increasing Lys from 12.6 to $18.6 \mathrm{~g} / \mathrm{kg}$ in the diet (Table 4; $P=0.0004$ ). These results were similar to those of Jones et al. (1967) who reported that excess dietary Lys would increase the Arg requirement of chicks by increasing its degradation through the activity of kidney arginase. Nesheim (1968) reported that chickens with a genetically higher requirement for Arg had a greater increase in arginase activity in response to an excess of dietary Lys than chickens with a lower Arg requirement. In Experiment 2, kidney arginase activity was unaffected by dietary Arg or Met $(P>0.05)$. No other interactions were found $(P>0.05)$ for arginase activity, indicating that Arg $\times$ Met interactions for growth were not due to changes in kidney arginase activity. An interaction between Arg and Lys was also not observed for kidney arginase activity in the present study $(P>0.05)$.

Arg is metabolized by at least two different pathways (Cynober et al. 1995). If Arg is converted to ornithine by arginase, the endproducts will be $\mathrm{CO}_{2}$, water and uric acid. If Arg is condensed with glycine and then methylated, the endproduct will be creatine. Creatine is either accumulated in muscle or is excreted as creatine or creatinine. If kidney arginase is increased, then less Arg should be available for creatine synthesis.

Austic \& Nesheim (1972) observed a large growth

Table 4. Kidney arginase activity and muscle creatine of chicks ( $n 8$ per replication per treatment) fed a maize-soyabean meal basal diet containing graded levels of arginine, methionine, and lysine for $14 \mathrm{~d}$ (Experiment 2$)^{\star}$

(Mean values with their standard errors)

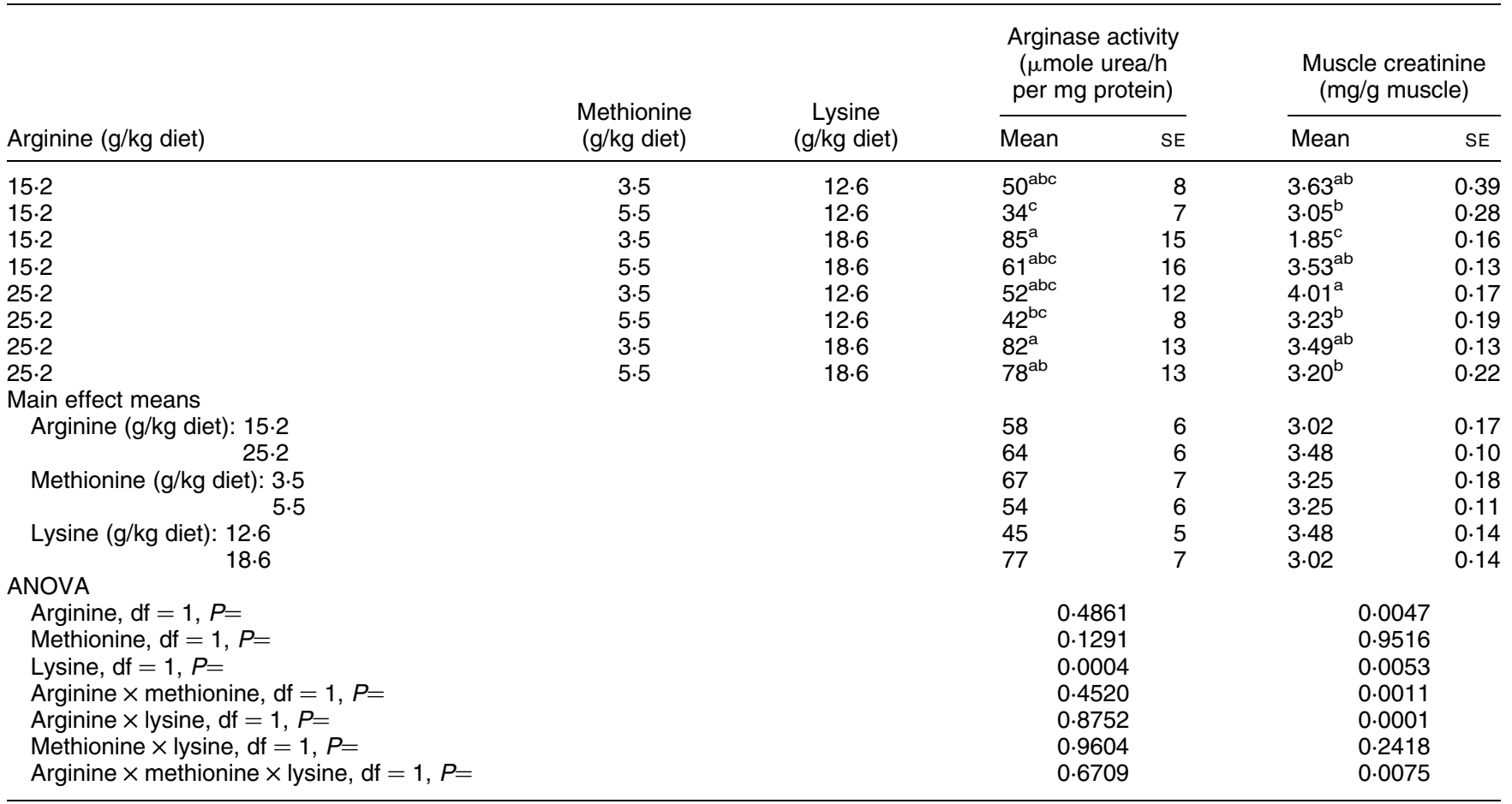

\footnotetext{
a,b,c Mean values within a column with unlike superscript letters were significantly different $(P<0.05)$
}

* For details of diets and procedures, see Table 1 and p. 656. 
response to dietary creatine in their high Arg requirement line, but not their low Arg requirement line. They attributed the effect of creatine on growth solely to sparing Arg otherwise used for creatine synthesis. Apparently chickens must maintain some minimum level of muscle creatine, or Arg will be transferred from other uses to creatine synthesis.

Muscle creatinine increased from 3.02 to $3.48 \mathrm{mg} / \mathrm{g}$ muscle when chicks were fed the higher dietary Arg level (from 15.2 to $25.2 \mathrm{~g} \mathrm{Arg} / \mathrm{kg} ; P=0.0047$ ) (Table 4). This result is similar to previous reports by Keshavarz \& Fuller $(1971 a, b)$. They reported that the addition of $20 \mathrm{~g} \mathrm{Arg} / \mathrm{kg}$ to a maize-soyabean-meal diet increased muscle creatine. Their results suggested that an increase in dietary Arg increased substrates involved in the creatine biosynthesis pathway. In our study, we found that breast muscle creatine was reduced when chicks were fed supplemental Lys $(P=0.0053)$. There are two possible explanations for how Lys reduced muscle creatine. First, an increase in dietary Lys increased arginase activity and thus possibly reduced the amount of Arg available for the creatine synthesis pathway. Second, an increase in dietary Lys may have decreased transamidinase activity. Transamidinase is the enzyme that utilizes Arg and glycine as substrates to produce guanidoacetone and ornithine in creatine biosynthesis. Jones et al. (1967) reported that transamidinase activity was decreased in chicks fed excess dietary Lys.

Highly significant $\operatorname{Arg} \times \operatorname{Met}(P=0 \cdot 0011)$ interactions were observed for muscle creatine (Table 4 ). These results suggest that at least creatine biosynthesis was involved in the Arg-Met interaction and the Met-Lys interaction. However, how they interact with each other has to be further investigated. A three-way interaction among Arg, Met, and Lys was found $(P=0.0075)$ for muscle creatine concentration, indicating that all three amino acids may be important in determining responses and requirements for any of the three.

To conclude, the null hypotheses tested here were found to be false. A dietary interrelationship was found among Arg, Met, and Lys in the present study. The interactions were probably the result of changes in Arg metabolism and creatine biosynthesis. These results suggest that more concern is prudent when considering the amino acid balance among Arg, Met, and Lys in the diet of young broiler chicks for maximum growth (and muscle creatine).

\section{Acknowledgements}

This study was supported by state and Hatch funds allocated to the Georgia Agricultural Stations of The University of Georgia.

\section{References}

Anderson JO \& Dobson DC (1959) Amino acid requirement of the chick. 2. Effect of total essential amino acid level in the diet on the arginine and lysine requirements. Poultry Science 38, $1140-1150$.
Austic RE \& Nesheim MC (1972) Arginine and creatine interrelationships in the chick. Poultry Science 51, 1098-1105.

Cynober L, Le Boucher J \& Vasson MP (1995) Review: Arginine metabolism in mammals. Journal of Nutrition and Biochemistry 6, 402-413.

Dean WF \& Scott HM (1968) Ability of arginine to reserve the growth depression induced by supplementing a crystalline amino acid diet with excess lysine. Poultry Science 47, 341-353.

D'Mello JPF \& Lewis D (1970) Amino acid interactions in chick nutrition. 1. The interrelationship between lysine and arginine. British Poultry Science 11, 299-311.

Fisher H, Salander RC \& Taylor MW (1956) The influence of creatine biosynthesis on the arginine requirement of chicks. Journal of Nutrition 59, 491-502.

Fuller HL, Chang SI \& Potter DK (1967) Detoxification of dietary tannic acid by chicks. Journal of Nutrition 91, 477-482.

Jones JD (1964) Lysine-arginine antagonism in the chick. Journal of Nutrition 84, 313-321.

Jones JD, Petersburg SJ \& Burnett PC (1967) The mechanism of the lysine-arginine antagonism in the chick: Effect of lysine on digestion, kidney arginase, and liver transaminase. Journal of Nutrition 93, 103-114.

Keshavarz K \& Fuller HL (1971a) Relationship of arginine and methionine in the nutrition of the chicks and the significance of creatine biosynthesis in their interaction. Journal of Nutrition 101, 217-222.

Keshavarz K \& Fuller HL (1971b) Relationship of arginine and methionine to creatine formation in chicks. Journal of Nutrition 101, 855-862.

Lewis D, Smith GH \& Payne CG (1963) Arginine in poultry nutrition. 1. Dietary requirement for arginine. British Journal of Nutrition 17, 415-431.

Lowry OH, Rosebrough NJ, Farr AL \& Randall RJ (1951) Protein measurement with the folin phenol reagent. Journal of Biological Chemistry 193, 265-275.

Marks DB, Marks AD \& Smith CM (1996) Basic Medical Biochemistry. Baltimore, MD: Williams \& Wilkins.

Montgomery DC (1997) Design and Analysis of Experiments. New York, NY: John Wiley \& Sons, Inc.

Nesheim MC (1968) Kidney arginase activity and lysine tolerance in strains of chickens selected for a high or low requirement for arginine. Journal of Nutrition 95, 79-87.

National Research Council (1994) Nutrient Requirements of Poultry. Washington, DC: National Academy Press.

O'Dell BL, Amos WH \& Savage JE (1965) Relation of chick kidney arginase to growth rate and dietary arginine. Proceedings of the Society of Experimental Biology and Medicine 118, $102-112$.

Rose WC, Helmer OM \& Chanutin A (1927) Amodified method for the estimation of total creatine in small amounts of tissue. Journal of Biological Chemistry 75, 543-552.

SAS Institute (1985) SAS ${ }^{\circledR}$ User's Guide. Cary, NC: SAS Institute, Inc.

Smith GH \& Lewis D (1966) Arginine in poultry nutrition. 3. Agent and target in amino acid interactions. British Journal of Nutrition 20, 621-631.

Steel RGD \& Torrie JH (1980) Principles and Procedure of Statistics. New York, NY: McGraw-Hill Book Co., Inc.

Tamir H \& Ratner S (1963) Enzymes of arginine metabolism in chicks. Archives of Biochemistry and Biophysics 102, $249-258$.

Van Slyke DD \& Archibald RM (1946) Gasometric and photometric measurement of arginase activity. Journal of Biological Chemistry 165, 293-300. 